INTIQAD: JURNAL AGAMA DAN PENDIDIKAN ISLAM

ISSN 1979-9950 (print) || ISSN 2598-0033 (online), http://jurnal.umsu.ac.id/index.php/intiqad DOI: https://doi.org/10.30596/intiqad.v11i1.2721

Vol. 11, No. 1 (Juni 2019)

\title{
Pemberdayaan Santri dalam Pemeliharaan Kebersihan dan Pengembangan Potensi Wisata Pesantren (Studi Kasus Pesantren Musthafawiyah)
}

\section{Fauziah Nasution}

Fakultas Dakwah dan Ilmu Komunikasi IAIN Padangsidimpuan email: fauziahnasution@iain-padangsidimpuan.ic.id

\begin{tabular}{|c|c|}
\hline Abstract & Artikel Info \\
\hline $\begin{array}{l}\text { Musthafawiyah Islamic Boarding School has played a role } \\
\text { in the field of education and da'wah for more than a } \\
\text { century. But the fact is that the santri which reached 12,578 } \\
\text { people and the environment of the pesantren which } \\
\text { mingled with the surrounding community created a } \\
\text { problem of maintaining cleanliness in the boarding school } \\
\text { environment. On the other hand, the existence of small } \\
\text { huts, the homes of the santri, has attracted the interest of } \\
\text { foreign and local tourists. It is unfortunate that this tourism } \\
\text { potential has not been managed properly. The } \\
\text { empowerment of santri through Participatory Action } \\
\text { Research turned out to be able to change the awareness of } \\
\text { santri about cleanliness maintenance and development of } \\
\text { Islamic boarding school tourism potential. This activity } \\
\text { involved the MADINA Regency government; Office of } \\
\text { Environment, Tourism Office, District and village } \\
\text { government, and pesantren alumni who are members of the } \\
\text { Arbituren Musthafawiyah Family organization (KAMUS) } \\
\text { Keywords : Empowerment, Santri, Musthafawiyah } \\
\text { Islamic Boarding School }\end{array}$ & $\begin{array}{c}\text { Received: } \\
\text { 21 Januari } 2019 \\
\text { Revised: } \\
\text { 14 Maret } 2019 \\
\text { Accepted: } \\
\text { 21 April } 2019 \\
\text { Published: } \\
\text { 17 Juni 2019 }\end{array}$ \\
\hline Abstrak & \\
\hline $\begin{array}{l}\text { Pesantren Musthafawiyah telah berperan dalam bidang } \\
\text { pendidikan dan dakwah lebih dari satu abad. Namun } \\
\text { kenyataannya dengan santri yang mencapai } 12.578 \text { orang } \\
\text { dan lingkungan pesantren yang berbaur dengan masyarakat } \\
\text { sekitar menimbulkan masalah pemeliharaan kebersihan di } \\
\text { lingkungan pondok pesantren. Disisi lain, keberadaan } \\
\text { pondok-pondok kecil, tempat tinggal para santri, telah } \\
\text { menarik minat wisatawan asing dan lokal. Sangat } \\
\text { disayangkan potensi wisata ini belum dikelola dengan baik. } \\
\text { Pemberdayaan santri melalui Participatory Action Research, } \\
\text { ternyata dapat merubah kesadaran santri akan pemeliharaan } \\
\text { kebersihan dan pengembangan potensi wisata pesantren. }\end{array}$ & \\
\hline
\end{tabular}


Kegiatan ini melibatkan pemerintah Kabupaten MADINA;

Dinas Lingkungan Hidup, dinas Pariwisata, pemerintahan

Kecamatan dan desa, serta alumni pesantren yang tergabung dalam organisasi Keluarga Arbituren Musthafawiyah

(KAMUS).

Kata Kunci : Pemberdayaan, Santri, Pesantren

\section{Musthafawiyah}

\section{A. Pendahuluan}

Pesantren merupakan lembaga pendidikan yang sudah berurat berakar di tengah-tengah masyarakat Indonesia. Keberadaannya tidak dapat dipisahkan dari masyarakat. Demikian juga dengan keberadaan pesantren Musthafawiyah Purbabaru. Pesantren ini telah eksis selama lebih dari satu abad dan merupakan pesantren tertua dan terbesar di daerah Sumatera Utara, dengan jumlah santri mencapai 12.578 orang. ${ }^{1}$

Sebagai lembaga pendidikan dan dakwah, pesantren ini idealnya menjadi ikon penerapan ajaran Islam secara kaffah. Namun dalam realitanya dengan jumlah santri yang sangat besar, dan sistem pesantren yang berbaur dengan masyarakat serta berbagai kondisi lainnya menimbulkan persoalan dalam pemeliharaan kebersihan di lingkungan

1 Data Pesantren Mushthafawiyah tahun pesantren. Peraturan Mentri Agama menyebutkan bahwa pnyelenggaraan pendidikan pesantren bertujuan: 1) Menanamkan keimanan dan ketakwaan kepada Allah swt. 2) Mengembangkan kemampuan, pengetahuan, sikap dan keterampilan peserta didik untuk menjadi ahli ilmu agama Islam (muttafaqqih fi al-din). 3) Mengembangkan pribadi Akhlak al karimah bagi peserta didik yang memiliki kesalehan individual dan sosial dengan menjunjung tinggi jiwa keikhlasan, kesederhanaan, kemandirian, persaudaraan sesama umat Islam (ukhuwah islmaiyah), rendah hati (tawadhu'), toleran (tasamuh) keseimbangan (tawazun), moderat (tawasuth), keteladanan (uswah) pola hidup sehat dan cinta tanah air. ${ }^{2}$ Dari data awal peneliti menemukan bahwa sistem pendidikan di pesantren

2 Peraturan Menteri Agama Nomor 13 Tahun 2014 tentang Pendidikan Keagamaan Islam, Pasal 2. 
Vol. 11, No. 1 (Juni 2019)

Musthafawiyah telah berhasil mencapai tujuan pendidikan dimaksud, namun masih sebatas tataran teori dan tidak dalam tataran praktis, khususnya dalam bidang pola hidup sehat/bersih. Inilah agaknya yang disebut problema keilmuan pesantren, yaitu terjadi kesenjangan, keterasingan dan pembedaan antara tataran teori dan praktek. Dalam realita, pengejawantahan ajaran Islam tentang kebersihan di lingkungan pesantren hampir tidak tanpak. Hal ini terlihat dengan sikap menjadikan aliran sungai Aek Singolot sebagai tempat pembuangan sampah, buang hajat bahkan mandi dan mencuci. Tidak adanya tempat sampah di sekitar pondok-pondok pokir dan tidak adanya truk pengangkut sampah santri ke tempat pembuangan akhir, Kondisi ini diperburuk dengan pondok pokir yang tidak hanya dibangun di atas lahan milik pesantren, tapi juga di atas lahan milik masyarakat yang mempersulit pembinaan dan pengawasan. Hal ini tentunya menuntut kerjasama yang baik antara masyarakat dengan pihak pesantren. Namun kenyataannya kesadaran dan partisipasi masyarakat sekitar sangat rendah. Disisi lain, letak strategis pesantren yang berada di jalan lintas sumatera, dengan keberadaan 1846 pondok-pondok kecil, sebagai sentral kehidupan para santri, kesederhanaan kehidupan santri yang menyatu dengan alam, memiliki keunikan dan menjadi ikon bagi pesantren ini untuk mendunia. Keunikan ini semakin menarik dengan adanya aktivitas harian ribuan santri dengan segala identitasnya; memakai sarung, gamis atau baju koko putih, jas hitam serta serban yang dililitkan rapi dikepala sambil menyandang kitab, sesungguhnya memiliki potensi destinasi wisata yang sangat tinggi dan menarik wisatawan asing dan lokal untuk berkunjung ke pesantren ini dari tahun ke tahun. Namun kondisi ini belum menjadi perhatian semua pihak, baik pesantren maupun pemerintah setempat.

Dari aspek pemberdayaan, pada dasarnya pondok pesantren dengan segala aspek tata nilai yang dimilikinya, mampu memberdayakan masyarakat, karena para aktor kyai dan santri memiliki perilaku moral religius yang menunjang aktivitas pemberdayaan masyarakat. ${ }^{3} \quad$ Kaitannya dengan

\footnotetext{
${ }^{3}$ M. Bashori Muchsin , Upaya Pondok Pesantren Dalam Pemberdayaan Masyarakat Sekitar Hutan (Efforts of the Pondok Pesantren
} 
INTIQAD: JURNAL AGAMA DAN PENDIDIKAN ISLAM

ISSN 1979-9950 (print) || ISSN 2598-0033 (online), http://jurnal.umsu.ac.id/index.php/intiqad

DOI: https://doi.org/10.30596/intiqad.v11i1.2721

Vol. 11, No. 1 (Juni 2019)

pemberdayaan santri dalam pemeliharaan kebersihan dan

pemeliharaan kebersihan dan pengembangan potensi wisata setelah

pengembangan potensi wisata dilakukan pendampingan?

lingkungan pesantren mustahafwiyah Sejauh pengetahuan penulis,

Purbabaru merupakan suatu hal yang penelitian tentang pemberdayaan santri

menarik untuk diteliti secara serius, pesantren Musthafawiyah masih sangat ilmiah dan mendalam. Hal ini sedikit, apalagi berkaitan dengan disebabkan dari jumlah santri yang pemeliharaan kebersihan dan mencapai 12.578 orang, merupakan pengembangan potensi wisata pesantren potensi sumber daya manusia yang dapat belum pernah dilakukan. Penelitidiberdayakan agar dapat mencapai posisi peneliti sebelumya lebih tertarik kepada ideal diatas, sebagai pemberdaya masyarakat sekitar.

Kondisi ini menimbulkan pemikiran untuk memberdayakan santri dalam mengatasi persoalan lemahnya pemeliharaan kebersihan dan pengembangan potensi wisata lingkungan pesantren melalui kegiatan pendampingan. Pemikiran ini menimbulkan pertanyaan bagaimana pemeliharaan kebersihan dan potensi wisata pesantren? apa saja bentuk kegiatan pendampingan yang dilakukan dalam rangka memberdayakan santri dalam pemeliharaan kebersihan dan pengembangan potensi wisata pesantren? dan apakah terjadi peningkatan

to Empower Societies Living at Surrounding Forest Areas), WACANA Vol. 12 No. 2 April 2009, h. 388 
mengaplikasikan sistem adaptasi dan interaksi. ${ }^{4}$

Dari uraian diatas maka penelitian ini memiliki beberapa tujuan yaitu; Pertama, untuk mengetahui dan mendeskripsikan pemeliharaan kebersihan di lingkungan pondok pesantren. Kedua, untuk mengetahui potensi wisata lingkungan pondok pesantren. Ketiga, untuk mengetahui bentuk-bentuk kegiatan pendampingan, sebagai upaya peningkatan pemeliharaan kebersihan dan pengembangan potensi wisata pesantren dan keempat untuk mengetahui peningkatan dalam pemeliharaan kebersihan dan pengembangan potensi wisata, setelah adanya program pendampingan. Hasil penelitian ini nantinya diharapkan dapat menjadi informasi penting dan berguna, sebagai sebuah kajian akademik, yang dapat dikembangkan dalam pemeliharaan kebersihan lingkungan pesantren dan pengembangan potensi wisata pondok pesantren. Pemberdayaan santri pada kedua bidang ini akan

\footnotetext{
${ }^{4}$ Rudi Hardianto, Pemberdayaan Santri Pondok Pesantren Musthafawiyah Di Era Globalisasi (Studi Kasus Pondok Pesantren Musthafawiyah) dalam Jurnal Al-Ishlah: Jurnal Pendidikan -Vol. 9, No. 2. 2017, h. 30.
}

memiliki danpak yang sangat signifikan bagi eksistensi pesantren sebagai sebagai lembaga pendidikan dan dakwah Islam. Kemudian dari sudut pandang ilmu sosial penelitian ini diharapkan juga dapat berguna untuk memperkaya empirik yang aktual mengenai solusi dalam menyelesaikan pemasalahan pemeliharaan kebersihan dan pengembangan potensi wisata pesantren serta menjadi data pembanding bagi penelitian sejenis.

\section{B. Pesantren dan Pemerdayaan}

Konsep pemberdayaan pesantren didasarkan pada peran pesantren di tengah-tengah masyarakat. Dalam tataran ideal pesantren bukan sematamata lembaga pendidikan yang mengajarkan, mengembangkan dan menyebarkan ilmu agama, melainkan juga lembaga masyarakat yang memiliki pranata sendiri yang memiliki fungsi amal terhadap masyarakat, khususnya yang ada dalam lingkungan pengaruhnya. ${ }^{5}$ Salah satu pesantren yang telah melakukan peran diatas adalah pesantren Dawar Boyolali Jawa Tengah. Pesantren ini memiliki kontribusi yang

5 Dawan Raharjo, Pesantren dan Pembangunan (Jakarta : LP3ES, 1983), h. 3 
besar bagi masyarakat sekitar melalui pengabdian keagamaan dan ekonomi umat. ${ }^{6}$ Realitas ini menunjukkan bahwa keberadaan pesantren di tengah-tengah masyarakat tidak dapat dinafikan dan dipisahkan dari masyarakat.

Pemberdayaan pada hakekatnya bertujuan membebaskan seseorang dari kendali yang kaku, memberi orang kebebasan untuk bertanggung jawab terhadap ide-idenya, keputusan keputusannya dan tindakantindakannya. $^{7} \quad$ Sementara $\quad$ Shardlow mengatakan bahwa "pemberdayaan membahas bagaimana individu, kelompok ataupun komunitas berusaha mengontrol kehidupan mereka sendiri dan membentuk masa depan sesuai dengan keinginan mereka". ${ }^{8}$ Dalam pelaksanaannya pemberdayaan memiliki tiga prinsip dasar yaitu: partisipasi, kemandirian dan keberlanjutan. Tiga prinsip dasar pemberdayaan ini sesuai

6 Rustam Ibrahim, pesantren dan pengabdian masyarakat, dalam jurnal Al-tahrir, Vo. 16 No. 1 h. 70

7 Deddy Mulyana, Komunikasi Antarbudaya (Bandung: Remaja Rosdakarya, 1998) h. viii

8 Cholisin, Pemberdayaan Masyarakat, Disampaikan pada Gladi Manajemen Pemerintahan Desa Bagi Kepala Bagian/Kepala Urusan Hasil Pengisian Tahun 2011 Di Lingkungan Kabupaten Sleman, 2011 dengan tujuan penyelenggaran pedidikan di pesantren sebagaimana tercantum dalam Peraturan Menteri Agama Nomor 13 Tahun 2014 tentang pendidikan keagamaan Islam pasal 2.

Dari tujuan penyelenggaraan pendidikan pesantren dapat dipahami bahwa pesantren memiliki tanggungjawab sosial dalam pemberdayaan masyarakat. Teori Max Weber yang menyatakan bahwa perubahan sosial sebagai danpak modernisasi harus memperhatikan manusia yang dibentuk oleh nilai-nilai budaya di sekitarnya, khususnya nilainilai agama yang tidak dapat dilepaskan dari kehidupan manusia. Salah satu topik masalah pembangunan yang dibahas Weber adalah tentang peran agama sebagai faktor yang menyebabkan munculnya paham kapitalisme yaitu dari the Protestant Ethic. Dalam banyak kasus prilaku keteladan dari para aktor perubahan sangat menentukan dan berbanding lurus dengan ajaran agama. ${ }^{9}$

${ }^{9}$ Weber, Max, Die Protestantische Ethik und der "Geist" des Kapitalismus, diterjemahkan oleh Talcott Parson, The Protestant Ethic and the spirit of capitalism, , New York: Char Les Scribner's Son, 1959, (terjemahan Yusuf Priyasudiarja, Etika Protestan dan Semangat Kapitalisme (Surabaya: Pustaka Promethea, 2002) h. 95. 
Berkenaan dengan peran pesantren, salah satu problema sistem pendidikan dan pengajaran di Pondok Pesantren dewasa ini adalah belum sepenuhnya diintegrasikan dengan kebutuhan masyarakat ${ }^{10}$. Dalam konteks ini Nurochim menawarkan satu model pendidikan Islam yang disebutnya Sekolah berbasis Pesantren (SBP) yaitu model pendidikan yang menggabungkan dua system sosial; system sosial pesantren dan system sosial sekolah dengan tujuan menghasilkan SDM yang agamawan dan ilmuan sehinga dapat berperan dalam masyarakat. ${ }^{11}$ Dalam banyak kasus hal ini didasarkan pada dikotomi keilmuan yang berimbas pada dualisme pendidikan; ${ }^{12}$ memisahkan antara ilmu-ilmu agama dan ilmu-ilmu umum, dan "terlepasnya" pendidikan nilai dalam proses pembelajaran. ${ }^{13}$ Pada

${ }^{11}$ Nurochim, Sekolah Berbasis Pesantren sebagai salah satu model pendidikan Islam dalam perubahan sosial, jurnal Al-Tahrir vol 16 No. 1 Mei 2016. h. 73

12 Dalam dunia pendidikan pesantren masih banyak ditemukan paradigma berfikir yang parsial dalam menilai kedudukan ilmu-ilmu pengetahuan. Sebagian masih memiliki pandangan bahwa ilmu pengetahuan masih di kotak-kotak dalam ukhrawi-oreanted dan sebagian lain pada duniawi-oreanted.

13 Permasalahan umum yang dihadapi pesantren adalah pengejawantahan ajaran Islam dasarnya pondok pesantren dengan segala aspek tata nilai yang dimilikinya, mampu memberdayakan masyarakat, karena para aktor seperti kyai dan santri memiliki perilaku moral religius yang menunjang aktivitas pemberdayaan berupa sikap: Ikhlas, I'tidal (sikap tegak lurus dengan dasar kejujuran yang tinggi). Sikap ini menjadikan seseorang tidak mudah dipengaruhi oleh kepentingan apapun. Kemudian sikap Alwasatoh (sifat keseimbangan dalam mengambil keputusan). Sifat alwasatoh mendorong kyai/santri memilih sikap konpromis dalam persoalan duniawiah. Sikap selanjutnya adalah Istiqomah (keajegan perilaku atau aktivitas yang terus menerus dilakukan dengan tekanan adanya peningkatan dalam kegiatan tersebut). Terakhir adalah sikap tawakkal, (sikap memahami batas kemampuan diri sendiri yang diwujutkan pada mawas diri dalam setiap

tentang kebersihan. Ada "kesan" bahwa pelajaran Fiqh khususnya bab thaharah terpisah dengan pengamalan kebersihan dalam kehidupan sehari-hari. Peneliti memahami bahwa aplikasi ajaran Islam tentang kebersihan dalam kehidupan merupakan wujud dari tafakkuh fiddiin. Tafakkuh fiddiin merupakan inti dari pendidikan pesantren dengan menjadikan Islam sebagai asas pengkajian keilmuannya. Sumadai, Islam dan Seksualitas: Bias Gender dalam humor Pesantren, dalam Jurnal el-harakah, Vol. 19, No. 1 Januari-Juni 2017, h. 22 
keberhasilan maupun kegagalan pada suatu usaha kegiatan). Dengan nilainilai yang terkandung dalam perilaku kyai/santri tersebut dimuka, maka akan mendorong kyai dan santri untuk memberdayakan masyarakat ${ }^{14}$ dalam berbagai bidang kehidupan.

Diantara tantangan global yang harus direspon oleh pesantren adalah sektor pariwisata. Menurut Pitana, dalam beberapa dasawarna terakhir, pariwisata telah menjadi sumber penggerak dinamika masyarakat dan menjadi salah satu prime-mover dalam perubahan social-budaya.${ }^{15}$ Hal ini tidak terlepas dari fenomena tipologi wisatawan. Menurut Cohen sebagaimana dikutip Pitana, wisatawan dapat di bagi kepada dua kelompok yaitu; (1) modern pilgrimage (ziarah modern) dan search for pleasure (mencari kesenangan). mencari "makna". Atas dasar fenomenology ini Cohen membedakan wisatawan menjadi:

${ }^{14}$ M. Bashori Muchsin , Upaya Pondok Pesantren Dalam Pemberdayaan Masyarakat Sekitar Hutan (Efforts of the Pondok Pesantren to Empower Societies Living at Surrounding Forest Areas), WACANA Vol. 12 No. 2 April 2009, h. 388

15 I Gede Pitana \& Putu Gayatri, Sosiologi Pariwisata,(Yogyakarta: Andi Offset, 2015), h. 34
1. Existensial yaitu wisatwan yang meninggalkan kehidupan sehari-hari dan mencari "pelarian" untuk mengembangkan kebutuhan spiritual . mereka bergabung intensif dengan masyarakat lokal.

2. Explerimental, yaitu wisatawan yang mencari gaya hidup yang berbeda dengan yang selama ini ia lakoni, dengan cara melakoni cara hidup masyarakat yang ia kunjungi. Wisatawan seperti ini secara langsunng terasimilasi ke dalam kehidupan masyarakat lokal.

3. Experential, yaitu wisatawan yang mencari makna pada kehidupan amsyarakat lokal, dan menikmati keaslian kehidupan lokal/tradisional

4. Diversionary, yaitu wisatawan yang mencari pelarian dari kehidupan rutin yang membosankan

5. Recreational, yaitu wisatawan yang melakukan perjalanan wisata sebagai bagian dari usaha menghibur diri atau relaksasi untuk memulihkan kembali semangat (fisik dan mentalnya). Mereka mencari lingkungan yang menyenangkan, umunya tidak mementingkan keaslian. ${ }^{16}$

${ }^{16}$ Ibid., h. 50 
Vol. 11, No. 1 (Juni 2019)

Sebagai lembaga sosial keagamaan, pesantren idealnya dapat merumuskan konsep wisata religi. Konsep ini sangat dibutuhkan dalam perkembangan sektor wisata dewasa ini. Hal ini semakin "berarti" ketika pada realitanya bahwa banyak pesantren memiliki potensi wisata yang belum "tersentuh". Peran kyai sebagai pengambil keputusan, penggerakkan, dan pendukung keputusan masyarakat, ${ }^{17}$ dalam menggerakkan sektor pariwisata relegi tentunya dapat menggerakkan masyarakat dalam mengantisipasi aspek negative pariwisata. Kyai, santri, pondok pesantren dan ajaran Islam, pada saat yang bersamaan semuanya memiliki kekuatan kreatif dan aktif membentuk dan mengubah struktur sosial serta institusi tradisi, begitu pula lingkungan sekitarnya dalam pengembangan sektor wisata di Indonesia. Karena tidak dapat dinafikan peran pariwisata dalam perekonomian masyarakat. Disinilah peran pesantren semakin nyata, dimana bukan hanya lembaga yang

17 M. Bashori Muchsin, Upaya Pondok Pesantren Dalam Pemberdayaan Masyarakat Sekitar Hutan (Efforts of the Pondok Pesantren to Empower Societies Living at Surrounding Forest Areas), WACANA Vol. 12 No. 2 April 2009, h. 398 menyelenggarakan kegiatan pendidikan bagi para santrinya, namun bisa mengayomi masyarakat sekitarnya serta menggerakkan roda-roda perekonomian masyarakat sekitar. ${ }^{18}$ Karena itu wacana pemberdayaan pesantren dalam sektor wisata merupakan satu tuntutan dunia pariwisata.

\section{Metode Penelitian}

Penelitian ini menggunakan metode Participatory Action Research (PAR), yaitu penelitian yang secara aktif melibatkan semua pihak yang terkait (stakeholders) dalam mengkaji tindakan yang sedang berlangsung dalam rangka melakukan perubahan dan perbaikan ke arah yang lebih baik. ${ }^{19}$ Pihak-pihak terkait dalam penelitian ini adalah pihak pesantren (yayasan, para guru, santri, dewan pelajar santri, pengurus organisasi kedaerahan dan pengurus banjar para santri) alumni pondok Pesantren Musthafawiyah yang tergabung di dalam Keluarga Arbituren Musthafawiyah (KAMUS), Pemerintah Kabupaten Madina; khususnya dinas Lingkungan

18 Husni Rahim, pola Pemberdayaan masyarakat Melalui pesantren, (Jakarta: Ditkapontren Kelembagaan Agama Depatemen Agama RI 2003, h. 20

19 Agus Afandi dkk, Modul Participatory Action Research (PAR) (Surabaya: Lembaga Pengabdian Masyarakat (LPM), 2013) h. 57-58 
Hidup, dinas pariwisata, aparat dua kategori; menetap di pesantren pemerintahan desa Purbabaru dan (santri mukim) dan yang tidak menetap kecamatan lembah Sorik Merapi. di pesantren (santri tidak mukim). Dengan Fokus dampingan 4945 orang santri mukim yang disebut dengan Pokir. Pemilihan metode ini karena pemanfaatan riset tindakan pada umunya adalah dalam bidang sosial, terutama dalam rangka melakukan perubahan atau perbaikan sosial. ${ }^{20}$ Karena penelitian ini hakekatnya berusaha menggali informasi secara mendalam terkait pemberdayaan santri dalam mengatasi persoalan pemeliharaan kebersihan dan pengembagan potensi wisata lingkungan pesantren Mustahfawiyah Purba.

\section{Hasil Analisis dan Pembahasan}

1. Pemeliharaan

Lingkungan

Musthafawiyah Purbabaru.

Kebersihan lingkungan pesantren Musthafawiyah tidak dapat dilepaskan dari keberadaan santri Musthafawiyah yang berjumlah 12.578 orang. ${ }^{21}$ Jumlah yang sangat fantastis ini, tentunya menimbulkan permasalahan dalam pemeliharaan kebersihan. Santri-santri ini dapat diklasifikasikan kepada santri

${ }^{20}$ Muhammad Ali, 2014, Memahami Riset Prilaku Sosial, Jakarta: Bumi Aksar, h. 350

${ }^{21}$ Data santri tahun 2018 Jumlah santri mukim (pokir berjumlah 5945 orang, para pokir ini menghuni pondok-pondok kecil yang berjumlah 1846 pondok dan tersebar di 35 banjar. ${ }^{22}$

Berdasarkan hasil observasi dan wawancara, kesadaran pemeliharaan kebersihan lingkungan pesantren masih sangat rendah. Sampah yang berserakan, sampai penumpukan sampah yang menggunung hingga menimbulkan bau yang tidak sedap di sekitar pondok pokir, disisi jembatan merah, di bantaran sungai Aek Singolot, di parit bahkan disepanjang jalan lintas sumatera dimana pesantren ini berada. Santri dan masyarakat terkesan membiarkan kondisi ini dan ada anggapan bahwa kondisi ini, sulit dirubah. Disekitar pondok-pondok pokir juga tidak didapati tempat sampah, bahkan tempat pembuangan sampahpun tidak ditemukan. Kenyataannya sampahsampah yang ada selama ini dibuang ke aliran sungai Aek Singolot, yang merupakan sentra thaharah para santri;

22 wawancara dengan sekretaris yayasan pada tanggal 20 April 2018 di kantor pesantren Musthafawiyah Purbabaru 


\section{Vol. 11, No. 1 (Juni 2019)}

mandi, menyuci pakaian bahkan berwudhu.

Berdasarkan data ini maka persoalan pemeliharaan kebersihan dan persoalan sampah adalah persoalan yang serius. Persoalan ini semakin konpleks, karena ternyata 1846 pondok pokir tidak hanya dibangun diatas lahan milik pesantren namun, juga milik masayarakat dengan cara sewa. ${ }^{23}$ Sementara pasrtisipasi masyarakat sekitar pondok sangat rendah. Yang lebih memprihatinkan sampah-sampah didominasi oleh sampah plastik yang sulit diurai dan sangat berbahaya bagi kesehatan. ${ }^{24}$ Sampah-sampah ini, tentunya membutuhkan pengelolaan maksimal, didukung sarana prasarana dan peraturan yang memadai.

Logika yang sangat sederhana tentang volume sampah yang dihasilkan para santri dalam satu hari dapat mencapai 17.835 sampah. Jumlah ini

${ }^{23}$ Wawancara dengan salah seorang pokir (berinisaial R) dan pemilik warung (berinisial U U) tanggal 4 Februari 2018. Pada saat wawancara jawaban "R" di aminkan oleh pokirpokir yang lain. Didukung dengan wawancara dengan salah seoranng alumni (berinisial KL) pada tanggal 1 dan 5 Maret 2018.

24 Indonesia bahkan masuk dalam peringkat kedua di dunia sebagai penghasil sampah plastik ke Laut setelah Tiongkok. Tri Wahyuni, CNN Indonesia | Selasa, 23/02/2016 07:01 WIB masih dihasilkan oleh santri mukim (pokir) yang berjumlah 6945 orang, dimana setiap satu orang pokir diperkirakan menghasilkan tiga sampah. Jumlah ini belum jumlah sampah yang dihasilkan oleh 12.578 santri yang beraktifitas sehari-hari di lingkungan pesantren ini. Bila 12.578 santri menghasilkan minimal tiga sampah dalam satu hari maka jumlah sampah minimal sehari adalah 37.734 sampah. Maka penelitian ini menemukan bahwa persoalan sampah di pesantren ini merupakan persoalan yang sangat luar biasa dan membutuhkan penyelesaian secepatnya. Kondisi kebersihan lingkungan pesantren ini sebenarnya telah menyita perhatian banyak pihak. Menurut Camat Kecamatan Lembah Sorik Merapi, kondisi kebersihan pesantren sangat memprihatinkan. Sungai Aek Singolotlah yang telah menyelamatkan sampah-sampah pokir dari tahun ke tahun. ${ }^{25}$

Peneliti menemukan bahwa banyak faktor yang mempengaruhi rendahnya kesadaran pokir dalam

25 Wawancara dengan Camat Lembah Sorik Merapi, 17 juli 2018 pukul 10.55-11.35 di kantor camat Lembah Sorik Merapi 
pemeliharaan kebersihan lingkungan pesantren, diantaranya adalah:

1) Sistem Pendidikan yang terpisah dari nilai, idealnya pendidikan keagaaman di pesantren tentang thaharah dan ibadah dapat dimanipestasikan dalam wujud kehidupan bersih dalam kehidupan sehari-hari santri. Pada kenyatannya antara tataran teori dan praktek jauh berbeda.

2) Bahwa kondisi ini sudah berlangsung bertahun-tahun, yang pada akhirnya menjadi budaya yang tidak baik dan diwariskan dari generasi ke generasi.

3) Jumlah pokir yang sangat besar, mencapai lebih dari 12.578 orang dari berbagai daerah dan latar belakang yang berbeda $^{26}$ adalah sumber penghasil sampah yang produktif. Jumlah ini bahkan mencapai populasi empat desa.

4) Keberadaan pondok-pondok sederhana sebagai sentra kehidupan pokir di pesantren musthafawiyah

${ }^{26}$ Setiap pelaksanaan shalat jumat, masjid pesantren tidak dapat menampung jumlah pokir, sehingga jamaah shalat tumpah ruah ke halaman sekolah bahkan trotoar jalan. Observasi 20 April, 13 Juli, 20 Juli dan 27 Juli 2018 pada saat pelaksanaan shalat jumat di pesantren Musthafawiyah. yang terletak di lingkungan pesantren bukan hanya milik pesantren, namun ada yang milik masyarakat dan dikelola masyarakat secara mandiri, dibangun pokir dengan cara sewa lahan. ${ }^{27}$ Kondisi ini tentunya menimbulkan saling lempar tanggungjawab. Ada kesan, masyarakat hanya menyewakan lahan saja, sementara masalah kebersihan adalah urusan pesantren. Sementara pihak pesantrenpun merasa bahwa pemilik lahan juga hendaknya memiliki tanggungjwab.

5) Rendah kesadaran dan partisipasi masyarakat sekitar; rata-rata masyarakat sekitar pondok pesantren memiliki usaha dagang untuk memenuhi keperluan harian ribuan pokir, mulai dari kebutuhan sehari-hari, kitab-kitab sampai lauk pauk dan jajanan. Namun dalam beberapa kali melintas di depan pesantren ini berdasarkan pengamatan peneliti, sampahsampah berserakan di lokasi dagang

${ }^{27}$ Wawancara dengan salah seorang pokir (berinisaial $\mathrm{R}$ ) dan pemilik warung (berinsial $\mathrm{U}$ U) tanggal 4 Februari 2018.pada saat wawancara jawaban "R" di aminkan oleh pokir-pokir yang lain. Didukung dengan wawancara dengan salah seorang alumni (berinisial KL) pada tanggal 1 dan 5 Maret 2018. 
yang terletak di pinggir jalan lintas provinsi. Hal ini tentunya sangat mengganggu pemandangan.

6) Rendahnya kesadaran para pokir dalam pemeliharaan kebersihan lingkungan pesantren bahkan ada kesan pesimis. ${ }^{28}$

7) Tidak adanya tempat pembuangan sampah; sampah-sampah yang dihasilkan para pokir bertahun-tahun di buang ke aliran sungai Aek Singolot.

8) Belum maksimalnya perhatian pihak pesantren dalam pemeliharaan kebersihan baik berupa sarana prasarana maupun peraturan yang mengikat secara tegas.

9) Perhatian pemerintah kabupaten MADINA masih terbatas pada pengelolaan sampah di lingkungan santriwati (fatayat) baik berupa pemberian tempat sampah, pembangunan bio gas, maupun kegiatan daur ulang sampah melalui Bank sampah. ${ }^{29}$ Sementara untuk

28 Wawancara dengan santri berinisial "H" pada saat gotong royong membangun mushalla di banjar Al-Anshar 14 Juli 2018. Menurutnya kalaupun dibersihkan akan kotor lagi.

${ }^{29}$ Wawancara dengan sekretaris Yayasan pesantren pada tanggal 29 April 2016. Didukung oleh wawancara dengan KADIS dan Sekretaris pokir yang mukim yang berjumlah 5945 orang, penggadaan tempat sampah hanya untuk para pokir yang tinggal di asrama. ${ }^{30}$

10) Tanggungjawab kebersihan lingkungan pesantren yang sangat luas berada dibawah komando satu orang guru, ${ }^{31}$ meskipun pada dasarnya setiap banjar ada "ayah" yang bertindak sebagai Pembina, namun kegiatan kebersihan di lapangan masih dibawah komando. Setelah berkoordinasi dengan pihak yayasan tentunya $^{32}$

11) Tidak adanya figur keteladanan baik dari tokoh-tokoh pokir seperti pengurus dewan pelajar. ${ }^{33}$

dinas Lingkungan hidup Kabupaten MADINA pada tanggal 15 Juli 2018

30 Wawancara dengan ayah Bangun tanggal 6 Mei 2018. Pada FGD ke dua yang dihadiri Kabid. Kebersihan DLH Kab. MADINA salah seorang peserta FGD mewakili ayah penanggungjawab banjar, juga meminta agar ada tempat sampah yang diletakkan di setiap banjar.

${ }^{31}$ Ayah Nu'aim adalah salah seorang guru senior yang diberi tanggungjawab mengomandoi kebersihan di lingkungan pesantren. Dalam melaksanakan perannya, beliau dibantu oleh ayah Bangun dan ayah-ayah lain yang bertanggungjwab atas banjar-banjar yang ditunjuk pesantren,

32 Observasi pada beberapa moment kunjungan ke lapangan sejak Mei sampai September 2018.

33 Kantor dewan pelajar masih terlihat kurang terawat, bahkan sampah-sampah berserakan di sekitar kantor dewan pelajar yang 
INTIQAD: JURNAL AGAMA DAN PENDIDIKAN ISLAM

ISSN 1979-9950 (print) || ISSN 2598-0033 (online), http://jurnal.umsu.ac.id/index.php/intiqad DOI: https://doi.org/10.30596/intiqad.v11i1.2721

Vol. 11, No. 1 (Juni 2019)

12) Belum adanya perhatian pemerintahan desa dan kecamatan akan pemeliharaan kebersihan lingkungan pesantren. Ada kesan bahwa besarnya pesantren ini maka "level"nya tidak lagi diurus oleh pemerintahan desa dan kecamatan tapi setinggat kabupaten. ${ }^{34}$

13) Kegiatan pemeliharaan kebersihan masih terbatas pada gotonng royong dan perlombaan kebersihan banjar, tidak secara rutin dilaksanakan.

14) Tidak sebandingnya jumlah "ayah" sebagai penanggungjawab kebersihan dengan jumlah pokir (pokir) yang harus dibina dan diawasi. $^{35}$

15) Organisasi akar rumput yang ada di kalangan pokir seperti dewan pelajar, organisasi kedaerahan pokir dan pengurus banjar sebagai pepanjangan tangan pesantren, belum menunjukkan partisipasi yang maksimal. ${ }^{36}$

letak dekat dengan jalan raya. Observasi pada tanggal 6 Mei 2018

34 Ini peneliti pahami dari wawancara dengan camat Lembah Sorik Merapi pada hari jumat tanggal 17 juli 2018.

35 Jumlah ayah penangungjawab banjar sebanyak 125 orang sementara santri penghuni pondok di 35 banjar sebanyak 5945 orang.

36 Masih ada sebagian pengurus dewan pelajar yang tidak mampu menjalankan tugasnya
2. Potensi Wisata Pesantren

\section{Musthafawiyah Purbabaru}

Dari pemetaan awal penelitian ini menemukan bahwa pesantren Musthafawiyah memiliki potensi wisata yang cukup tinggi, namun potensi ini belum menjadi perhatian sama sekali, sehingga potensi wisata ini belum di kembangkan. Diantara potensi itu adalah:

\section{a. Pesantren ini memiliki "keunikan" yang sangat spesial berupa:}

1) Keberadaan pondok-pondok kecil sebagai sentra kehidupan para pokir, menjadi ikon tersendiri bagi pesantren ini. Siapapun yang melintas di depan lokasi pesantren ini, dapat dipastikan tertarik dengan keberadaaan 1846 pondok yang berjejer di sisi kiri dan kanan jalan lintas Sumatera yang terletak di desa Purbabaru Kecamatan lembah Sorik

dengan maksimal. Peneliti berkesimpulan, ada beberapa faktor yang menyebabkannya diantaranya SDM yang kurang kualifide, sehingga tidak mampu menjadi leader yang menyatukan keragaman para santri. Ditambah lagi dengan banyak santri dan luasnya lingkungan pesantren membuat beberapa informasi penting tidak tersampaikan kepada seluruh santri. Wawancara dengan beberapa orang santri dan observasi 28 Juli 2018. 
INTIQAD: JURNAL AGAMA DAN PENDIDIKAN ISLAM

ISSN 1979-9950 (print) || ISSN 2598-0033 (online), http://jurnal.umsu.ac.id/index.php/intiqad

DOI: https://doi.org/10.30596/intiqad.v11i1.2721

Vol. 11, No. 1 (Juni 2019)

Merapi Kabupaten MADINA.

Keberadaan pondok-pondok

kecil dengan ukuran yang

berfariasi antara $2 \times 2 \mathrm{~m}, 3 \times 3 \mathrm{~m}$,

$3 \mathrm{X} 4 \mathrm{~m}$. atau bahkan ada yang

$1.5 \times 2 \mathrm{~m}^{37}$ berdindingkan

papan dan beratapkan rumbia atau seng ${ }^{38}$ menjadi ciri khas

pesantren Musthafawiyah.

Keunikan ini merupakan salah satu faktor yang membuat pesantren ini "mendunia".

Di pondok-pondok kecil ini pokir melakukan aktifitas harian seperti tidur, makan, belajar bahkan memasak. Dari beberapa pondok yang peneliti temukan juga tersedia tempat untuk memasak atau dapur kecil. Pondok-pondok ini dihuni oleh 2-3 orang pokir. Bila malam hari para pokir beristirahat dengan alas seadanya diatas lantai pondok yang terbuat dari papan. Sebagian pondok bahkan dibangun dengan ala kadarnya, sekedar dapat berdiri dan dapat ditempati. Untuk menghemat tempat, barang-barang pokir seperti; baju, tas

\footnotetext{
${ }^{37}$ Observasi dan informasi dari peserta duta kebersihan dan duta pariwisata pada saat penilaian duta kebersihan dan pariwisata di aula Musthafawiyah, 18 Agustus 2018

${ }^{38}$ Observasi kondisi pondok-pondok sejak april-september 2018
}

bahkan beras diletakkan diatas rak-rak yang dibuat didinding pondok. ${ }^{39}$ Terutama kitab-kitab yang dijadikan bahan pelajaran. Peletakan kitab-kitab di posisi atas merupakan satu tradisi keilmuan yang masih dilestarikan di kalangan pokir Musthafawiyah secara keseluruhan. Bahwa menurut mereka ini adalah petuah "ayah" yang berperan sebagai guru dan sudah menjadi tradisi pesantren bahwa salah satu sikap memuliakan ilmu adalah dengan memuliakan kitab/buku. Sehingga buku/kitab tersebut tidak boleh diletakkan sembarangan/ sejajar dengan tempat duduk, karena akan

${ }^{39}$ Observasi ke banjar Asy-Syuja'ah, pada tanggal 23 Juli 2018. Pondok yang peneliti kunjungi terletak dibawah pohon bambu dan sangat dekat dengan bantaran sungai Aek Singolot. Gemercik air yang jatuh di atas batu sungai serta arus sungai yang deras terdengar jelas di pondok ini. Ketika peneliti mendapat izin masuk ke dalam salah satu pondok, peneliti merasakan udara yang dingin dan sejuk, serta ada rasa "nyaman" yang tidak dapat peneliti ungkapkan dengan kata. Beberapa waktu di pondok ini melahirkan "makna" akan "apa" yang peneliti peroleh sebagai rizki dari Allah swt. Di pondok itu juga peneliti melihat satu ruangan kecil yang berukuran $1 \times 1$ M. yang ditutupi kain sebagai pembatas dengan ruang utama. Ternyata ruang itu difungsikan sebagai dapur kecil; tersedia kompor, periuk nasi dan wajan kecil serta ember tempat peralatan mandi pokir. 
menyebabkan tidak berkahnya ilmu yang dipelajari. $^{40}$

Keberadaan pondok-pondok ini dapat diklasifikasikan kepada 35 banjar. Banjar-banjar ini pada umumnya terbentuk atas nama kedaerahan, dan memakai nama Ulama dan tempat istimewa dalam Islam. Penghuni banjar dibawah koordinasi pengurus banjar yang dipilih secara demokrasi. Masingmasing banjar memiliki mushalla dan kantor/office. Mushalla dipergunakan santri untuk shalat lima waktu. Pelaksanaan shalat lima waktu di mushalla dikarenakan masjid pesantren tidak dapat menampung keseluruhan santri Musthafawiyah. Sementara kantor/office ini berfungsi sebagai tempat musyawarah, latihan muhadharah dan kegiatan banjar lainnya. selain itu office juga berfungsi sebagai tempat tinggal bagi orangtua yang berasal dari luar daerah yang berkunjung ke Musthafawiyah. ${ }^{41}$ Keberadaan 1846 pondok ini tentunya menyimpan ribuan kenangan bagi para pokir terutama bagi para alumninya yang

40 Wawancara dengan beberapa santri, 14 Juli 2018 di banjar al-Anshor.

${ }^{41}$ Wawancara dengan beberapa santri di banjar Lancang Kuning., 14 Juli dan 13 Agustus 2018 telah mendunia. Oleh karena itu meski ada wacana dan bahkan sudah menjadi rencana yang sudah mulai direalisasikan untuk membangun asrama bagi para santri, peneliti merekomendasikan pondok-pondok bersejarah tersebut tidak dimusnahkan. Melainkan dipelihara sebagai suatu benda bersejarah, yang telah melahirkan tokoh nasional bahkan internasional.

2) Aktivitas harian ribuan pokir

Penampilan khas pokir; memakai sarung, baju koko putih, jas hitam dan serban di kepala, mendekap kitab didada sebelah kanan, menjadi pemandangan yang menyejukkan hati. Dalam kunjungan terakhir peneliti ke lokasi penelitian tanggal 3 oktober 2018 lalu, bertepatan memasuki waktu shalat zhuhur, ratusan santri bahkan mencapai seribuan santri, dengan pakaian khasnya berserban, bersarung dan memakai baju koko/kemeja putih memenuhi jalan raya menuju masjid terdekat untuk melaksanakan shalat zhuhur. ${ }^{42}$

Pemandangan unik ini sebenarnya memiliki nilai wisata religi yang sangat tinggi. Di saat banyak generasi millennial yang terbuai dengan kemajuan tekhnologi, kehidupan bebas

\footnotetext{
${ }^{42}$ Observasi pada tanggal 3 oktober 2018
} 
remaja, masih ada ribuan generasi millineal yang memilih "jalan dakwah" mengisi masa mudanya. Bila ini "dikemas" dengan baik, dapat dipastikan akan sangat dinikmati para wisatawan yang mengalami kegersangan batin dan jenuh akan kehidupan duniawi. Atau bahkan sangat menarik bagi wisatawan mancanegara yang menyukai kultur yang unik.

\section{b. Posisi pesantren yang strategis untuk pusat wisata, terletak di tepi Jalan Lintas Sumatera.}

Banyak lokasi destinasi wisata terhambat pengembangannya karena posisinya yang kurang strategis. Namun berbeda dengan posisi pesantren Musthafawiyah yang terletak di sepanjang jalan lintas sumatera/nasional. Bahkan analisis peneliti potensi pesantren ini sebagai destinasi wisata melebihi dari potensi bukit muhasabah yang juga ada di Kabupaten MADINA. Tanpa promosi khusus, keberadaan pesantren ini dengan segala keunikannya telah menyebar dari mulut ke mulut setiap orang yang melintasinya.

\section{c. Kunjungan wisatawan asing dan lokal ke pondok pesantren dan Perubahan "arah" wisata modern ke alam dan wisata rohani.}

Kondisi ini bila dikaitkan dengan klasifikasi wisatawan yang dapat digolongkan kepada modern pilgrimage dan tipe search for pleasure, maka kondisi pesantren sangat tepat untuk kedua kategori wisatawan ini. Kategori Modern pilgrimage, (atau apa yang lebih dikenal dengan istilah ziarah modern) adalah exixtensial, experimental dan experiential. Dimana ketiga tipe wisatawan ini lebih menitik beratkan pada spiritual centre maupun culture centre. Hampir sama dengan modern pilgrimage, wisatawan wonderlust adalah wisatawan yang melakukan perjalanan karena dorongan untuk mendapatkan pengalaman baru, mengetahui kebudayaan baru, atau bahkan hanya untuk menggagumi keindahan alam yang belum pernah dilihat. Wisatawan seperti ini tertarik pada keunikan budaya dan pemandangan alam yang mempunyai nilai pembelajaran yang tinggi. ${ }^{43}$

Disinilah sebenarnya potensi wisata lingkungan pondok pesantren Musthafawiyah, "keunikan" budaya dan gaya hidup para pokir dengan pondokpondok kecilnya, kemandirian santrinya

43 I Gde Pinata dan Putu Gayatri, Sosiologi Wisata, h.56 
diusia yang masih sangat belia, ${ }^{44}$ dan dalam populasi yang sangat besar, mencapai 12.578 orang. Tentunya sangat menarik bagi para wisatawan type modern pilgrimage dan wonderlust. Kehadiran pondok-pondok kecil ditepi sungai Aek Singolot, bebatuan, gemercik air, arus sungai Aek singolot, "karamah" sungai Aek singolot yang tidak dapat dihuni oleh makhluk air, sampai eksistensi sungai Aek Singolot sebagai sentra thaharah para santri adalah "satu hal yang sangat unik" untuk di"sajikan" dalam bingkai wisata rohani.

\section{Kegiatan- Kegiatan Dalam Pemberdayaan Santri Pesantren Musthafawiyah Dalam Pemeliharaan Kebersihan Dan Pengembangan Potensi Wisata Pesantren Musthafawiyah Purbabaru.}

Sebagai sebuah penelitian PAR maka kegiatan awal penelitian ini adalah

44 Salah seorang alumni berinisal LK berkisah, tentang "kisah manisnya" di pondok perjuangan selama ia menuntut ilmu. Diusia yang belum genap 12 tahun ia sudah diantar orangtuanya untuk mondok di Musthafawiyah. Baru dua malam menjadi pokir, dimalam kedua hujan turun dengan lebatnya dan ia harus menerima kenyataan bahwa pondoknya bocor. Terpaksa ia tidur sambil duduk, mendekap kedua kaki menahan dinginnya malam. Keesokan paginya barulah ia minta tolong pada "tulang" sebutan untuk pokir yang sudah senior, biasanya duduk di kelas tujuh untuk mempebaiki pondoknya yang bocor. Wawacara 19 Juli 2018. dengan membangun hubungan kemanusiaan, peneliti melakukan inkulturasi $^{45}$ dan membangun kepercayaan (trust building) dengan para pokir dan pihak pesantren sehingga terjali hubungan yang saling mendukung. Langkah ini dilakukan agar peneliti dapat menyatu menjadi simbiosis mutualisme untuk melakukan riset, belajar memahami masalahnya, dan memecahkan persoalannya bersamasama (partisipatif) dengan para pokir, dengan tujuan semua pokir dapat berpartisipasi dalam aksi perubahan yang akan dilaksanakan.

Pemberdayaan santri diawali dengan membuka kesadaran dan wawasan santri akan kebersihan dan potensi wisata pesantren yang dibangun melalui kegiatan Focus Group Discussion (FGD), pencerahan dan pelatihan. dari langkah awal ini kemudian diputuskan untuk bekerjasama dengan stakeholder,yaitu pemerintahan

45 Dalam hal ini peneliti dibantu tim peneliti, meninjau langsung dan berbaur langsung dengan para pokir sejak bulan April, Mei dan kemudian dilanjutkan pada bulan Juli 2018. Proses membangun hubungan ini dimaksimalkan disebabkan pokir libur dua minggu sebelum Ramadhan dan aktif lagi setelah dua minggu lebaran. 
Vol. 11, No. 1 (Juni 2019)

kabupaten MADINA. ${ }^{46}$ Secara spesifik dibagi atas; untuk mengatasi permasalahan rendahnya pemeliharaan kebersihan lingkungan pesantren; rendahnya kesadaran santri dan ketiadaan truk pengangkut sampah maka diputuskan untuk bekerjasama dengan dinas Lingkungan Hidup Kabupaten MADINA. Tindak lanjut kerjaasama ini adalah dinas Lingkungan Hidup Kab. Madina mendukung dan terlibat secara penuh pada kegiatan pemberdayaan santri. Bentuk komitemen tersebut adalah dalam bentuk: 1) penyediaan truk pengangkutan sampah, untuk mengangkut sampah para santri dua kali dalam satu minggu, yaitu kamis dan minggu; 2) mengirimkan SDM sebagai narasumber untuk memberikan pencerahan tentang kebersihan bagi para santri, baik pada saat pelaksanaan FGD maupun pelatihan daur ulang sampah; 3) kesediaan sebagai dewan juri pada perlombaan kebersihan antar banjar dan pemilihan duta kebersihan dari kalangan

46 Sudah adanya izin pelaksanaan dari Kesbang. Pol. Kabuoaten MADINA ( no surat 070/45/BKBP/2018) bahkan ketika beraudiensi KABAN Kesbang. Pol menyarankan agar kegiatan lounching pesantren sebagai destinasi wisata rohani diundurkan pada peringatan 1 Muharram $1440 \quad \mathrm{H}$. Audiensi sekaligus wawancara dengan KABAN kesbang.pol. di ruang kerja beliau pada tanggal 14 Juli 2018 santri. Sedangkan untuk perkembangan potensi wisata pesantren pesantren, kerjasama dilaksanakan dengan dinas Pariwisata Kabupaten MADINA. Tindaklanjut kerjasama ini adalah kesediaan dinas pariwisata dalam kegiatan pemberdayaan santri melalui; pemberian wawasan dan pelatihan tentang kepariwisataan, kesediaan menjadi dewan juri dalam pemilihan duta pariwisata dari kalangan santri. Sementara untuk meningkatkan partisipasi masyarakat sekitar pesantren terhadap pemeliharaan kebersihan lingkungan pesantren, maka kerjasama dan dukungan pemerintah desa dan pemerintah Kecamatan.

Aksi perubahan dilakukan secara simultan dan partisipatif. Program pemecahan kemanusiaan bukan sekedar untuk menyelesaikan persoalan pemeliharaan kebersihan dan pengembangan potensi wisata pesantren semata, tetapi merupakan proses pembelajaran bagi pokir, sehingga terbangun pranata baru dalm komunitas dan sekaligus memunculkan community organizer (pengorganisir dari kalangan pokir sendiri) dan akhirnya muncul local leader (pemimpin lokal) yang menjadi perilaku dan pemimpin perubahan. Aksi 
INTIQAD: JURNAL AGAMA DAN PENDIDIKAN ISLAM

ISSN 1979-9950 (print) || ISSN 2598-0033 (online), http://jurnal.umsu.ac.id/index.php/intiqad DOI: https://doi.org/10.30596/intiqad.v11i1.2721

Vol. 11, No. 1 (Juni 2019)

perubahan dilaksanakan dengan penekanan pada masalah pemeliharaan kebersihan melalui gerakan kebersihan di lingkungan pesantren. Dimulai dengan gerakan aksi kebersihan di banjar alAnshar dan sekitarnya. ${ }^{47}$ Pemilihan banjar ini dikarenakan peneliti menilai adanya sikap kemandirian pokir yang menetap di banjar Al-Anshar dalam membangun mushalla untuk penghuni banjar. $^{48}$ Potensi kemandirian dan partisipasi ini memerlukan upaya pengembangan yang maksimal. Pada awal gerakan perubahan peneliti merencanakan akan mengambil beberapa banjar sebagai pilot projek, namun dalam FGD ke-1 tentang darimana, kapan dan bagaimana aksi peruabhan dilakukan maka diputuskan bahwa kegiatan pemberdayaan melalui aksi perubahan ini dilakukan secara global, di seluruh lingkungan pesantren.

Untuk itu pada tahap selanjutnya peneliti membangun pusat-pusat belajar masyarakat, yang dibangun atas dasar kebutuhan kelompok-kelompok

47 Kegiatan ini dilaksanakan pada 27 April 2018. Atas dasar pertimbangan pokir yang akan libur, maka gerakan ini diharapkan dapat menumbuhkan kesadaran subyek pendampingan yang lain.

48 Wawancara dengan penanggungjawab bidang keamanan pesantren, pada 15 Juli 2018. komunitas yang sudah bergerak melakukan aksi perubahan. Pusat belajar merupakan media komunikasi, riset, diskusi, dan segala aspek untuk merencanakan, mengorganisir dan memecahkan problem sosial. Kegiatan ini dilakukan peneliti di kampus, di kantor pesantren, bahkan di banjarbanjar pesantren. Hal ini disebabkan luasnya lokasi pesantren dan tersebarnya pondok-pondok pada 35 banjar. Kegiatan ini juga dilaksanakan di kantor dinas kebersihan dan pariwisata kabupaten MADINA. Pada kesempatan tersebut dinas kebersihan kembali menekankan perlu keterlibatan pemerintahan Kecamatan dan desa dimana pesantren berada. Kegiatan Terakhir di kantor pemerintah kecamatan Lembah Sorik Merapi. Langkah ini dilakukan mengingat besarnya jumlah subyek pendampingan dan berbaurnya pesantren dengan masyarakat. Langkah selanjutnya yang sangat penting dalam penelitian PAR adalah melakukan Refleksi (teoritisasi perubahan sosial), pada tahap ini, peneliti bersama komunitas merumuskan teoritisasi perubahan sosial.

Berdasarkan hasil riset, proses pembelajaran masyarakat, dan program- 
Vol. 11, No. 1 (Juni 2019)

program aksi yang sudah terlaksana, peneliti dan komunitas merefleksikan semua proses dan hasil yang diperolehnya (dari awal sampai akhir). Beberapa kali ini sudah dilakukan peneliti, dalam lingkup terbatas. Namun diakhir penelitian refleksi dilaksanakan dalam skop lebih besar yaitu dengan melibatkan semua unsur yang terkait baik pemerintahan kabupaten MADINA dengan harapan ada kebijakan pemerintah dalam pemeliharaan kebersihan dan pengembangan potensi wisata. Hasil refleksi ini diharapkan dapat menjadi informasi penting dan berguna bagi pemerintah kabupaten MADINA, sebagai sebuah kajian akademik, yang dapat dikembangan dalam pemeliharaan kebersihan lingkungan dan potensi wisata lingkungan pesantren mustahfawiyah. Kegiatan ini merupakan desiminasi hasil penelitian dalam rangka perinngatan 1 Muharram $1440 \mathrm{H}$. yang dihadiri ribuan santri, ayah dan ibu guru pesantren, unsur pimpinan pesantren, pemerintah Kabupaten MADINA dan KAMUS. Pada tahap ini peneliti merekomendasikan perlunya perhatian dan komitmen yang serius baik pihak pesantren maupun pihak pemerintah kabupaten MADINA

dalam

pemeliharaan kebersihan lingkungan pesantren.

Komitmen tersebut dapat diawali dengan kontrak kerjasama antara pemerintah dengan pihak pesantren. Peneliti menyarankan, utuk pengembangan potensi wisata dapat dikembangkan dengan membangun musium syek Musthafa Huesin nasution. Hal ini dibutuhkan agar sejarah dan peninggalan-peninggalan beliau dapat terjaga dan terwarisi dari generasi ke generasi.

Meluaskan skala gerakan dan dukungan; untuk menjamin adanya keberlanjutan program (sustainability) yang sudah berjalan dan munculnya pengorganisir-pengorganisir serta pemimpin lokal yang melanjutkan program untuk melakukan aksi perubahanan. Pada kondisi ini pokir sudah mampu memobilitasi sendiri adalah bentuk partisipasi dimana pokir mengambil inisiatif, melaksanakan kegiatan, pada berbagai tahap secara mandiri dan mobilisasi sumber daya yang dibutuhkan dari kalangan pokir sendiri. Pada akhirnya pokir diharapkan mampu mandiri dalam berpikir, bersikap, dan mengambil tindakan serta 
sudah mampu berorientasi jangka panjang, makro dan subtansial, dalam artian pokir sudah berada dalam tahap terberdayakan. Wujud keberdayaan pokir ini terwujud pada gerakan kebersihan massal yang dilaksanakan pesantren pada tanggal 27 Juli 2018 dari pukul 08.00-10.00. Kegiatan ini tentunya tidak terlepas dari dukungan pihak yayasan pesantren yang menghentikan semua kegaitan pembelajaran. Satu hal yang tidak dapat dilepaskan adalah bahwa pola komunikasi antara kyai dan pokir memiliki pengaruh dalam mobilisasi pokir. ${ }^{49}$

Berdasarkan hasil evaluasi peneliti terhadap semua program pemberdayaan yang sudah peneliti laksanakan maka untuk mewujudkan keberlanjutan program (sustainability) dan dilaksanakan dengan melaksanakan perlombaan kebersihan antar banjar dan

${ }^{49}$ Salah satu konstruksi komunikasi yang efektif di pesantren, dilihat dari seorang kiai dan ustadz membawa karismanya sehingga tingkat kredibilitas di hadapan pokir begitu tinggi. Implikasinya pada aktivitas-rutinitas di pesantren, seorang pokir percaya sepenuhnya kepada kiai dan ustadz sehingga benar-benar perkataannya didengarkan, perbuatannya dipercaya dan ditiru. Lihat Rudi Hartono, Pola Komunikasi di Pesantren: Studi tentang Model Komunikasi antara Kiai, Ustadz, dan Pokir di Pondok Pesantren TMI Al-Amien Prenduan, dalam Jurnal al-Balagah, h. 90. http://ejournal.iain-surakarta.ac.id pemilihan duta kebersihan dan duta wisata. $^{50}$ Puncak kegiatan ini adalah pada acara peringatan 1 muharram 1440 H. ${ }^{51}$ Dengan terpilihnya banjar terbersih pringkat $1,2,3,4,5 \& 6$ serta nominasi 1, 2 \& 3 duta kebersihan dan duta pariwisata, dilanjutkan pemilihan Runner up duta kebersihan dan duta pariwisata maka diharapkan "lahir" pengorganisir-pengorganisir serta pemimpin lokal yang melanjutkan program untuk melakukan aksi perubahanan.

4. Peningkatan

Pemeliharaan Kebersihan Di Lingkungan Pesantren dan Pengembangan Potensi Pesantren Musthafawiyah Sebagai Destinasi Wisata Setelah Mengikuti Program Pendampingan.

Sesuai Dengan jenis penelitian yaitu PAR dengan tujuan pemberdayaan,

${ }^{50}$ Ide ini merupakan hasil FGD dengan permasalahan apa upaya agar aksi perubahan dapat berlanjut dan tidak berhenti. Maka diputuskan diadakan lomba kebersihan antar Banjar dan pemilihan duta wisata dan duta kebersihan dari kalangan santri. Penilaian dan penentuan pemenang lomba melibatkan dinas LDH, dinas pariwisata, pihak pesantren dan keluarga arbituren Musthafawiyah (KAMUS).

${ }^{51}$ Kegiatan ini dilaksanakan pada saat peringatan tahun baru hijrah 1 Muharam $1440 \mathrm{H}$ bersamaan dengan desiminasi hasil penelitian di halaman utama pondok pesantren Musthafawiyah. Sesuai kesepakatan dengan pihak pesantren dan para stkeholder pada tanggal 18 Agt. 2018 di kantor pesantren Mustahafwiyah. 
maka dalam pelaksanaannya penelitian ini akan didasarkan pada tiga (3) prinsip dasar PAR yaitu: partisipasi, kemandirian dan berkelanjutan.

Berdasarkan data di lapangan partisipasi dan kemandirian pokir sudah mulai tumbuh dalam hal pemeliharaan kebersihan dan pengembangan potensi wisata pesantren. Hal ini ditandai dengan adanya gerakan pemeliharaan kebersihan dalam wujud gotong royong. Jadwal gotong royong setiap hari senin, mulai intens di laksanakan di bawah koordinasi pengurus-pengurus banjar. Himbauan untuk mengumpulkan sampah di hari kamis dan minggupun mulai menunjukkan hasil yang mengembirakan. Bila pada awalnya gotong royong massal didampingi tim peneliti, namun pada tanggal $27 \mathrm{Juli}$ 2018 tanpa kehadiran tim peneliti, pokir sebagai subyek pendampingan bergerak secara berjamaah membersihkan lingkungan pesantren dari sampahsampah yang berserakan.

Upaya menumbuhkan partisipasi pokir dalam pemeliharaan kebersihan dan pengembangan potensi wisata pesantren diawali dengan cara menggugah kesadaran pokir bahwa adanya realitas kompleksitas permasalahan berkenaan dengan pemeliharaan kebersihan lingkungan pondok pesantren, serta perlunya tindakan konkret dalam mengupayakan perbaikan dalam budaya hidup pokir. Kesadaran pokir digugah melalui dialog dan diskusi bahwa tidak ada guna ilmu yang banyak bila tidak diamalkan. Realitanya hampir $80 \%$ dari pokir yang hadir pada pertemuan pertama dengan pokir di gedung perpustakaan pesantren Mustyhafawiyah, dengan retorika yang baik mampu menyampaikan ajaran Islam tentang kebersihan. $^{52}$ Namun penguasaan materi dan kemampuan retorika yang baik tidak sesuai dengan prilaku sehari-hari dalam membuang sampah. Kesadaran pokir juga dibangun peneliti dengan langsung menjadi contoh gerakan aksi kebersihan, mengumpul sampah pada tempatnya, dan memberikan satu slogan "satu sampah adalah satu dosa dan satu sampah adalah satu pahala". Sedangkan partisipasi yang ingin dibangun melalui program pemberdayaan pokir dilaksanakan secara bertahap, dimulai dari jenis partisipasi interaktif menuju tumbuhnya mobilitas sendiri (self-mobilization) di kalangan pokir dalam pemeliharaan kebersihan

52 Observasi 14 April 2018 
Vol. 11, No. 1 (Juni 2019)

maupun pengembangan potensi wisata pesantren. Pada akhirnya pokir diharapkan mampu mandiri dalam berpikir, bersikap, dan mengambil tindakan serta sudah mampu berorientasi jangka panjang, makro dan subtansial berarti mereka sudah berada dalam tahap terberdayakan. Konsep pemberdayaan ini sebenarnya berangkat dari pandangan yang menempatkan manusia sebagai subjek dari dunianya sendiri.

Dari beberapa kali gerakan aksi perubahan dapat dilihat perubahan kondisi kebersihan lingkungan pesantren. Hal ini tidak lain karena problema sampah mulai diuraikan sedikit demi sedikit melalui aksi kebersihan yang dikoordimir oleh pesantren. Dalam hal ini "ayah" memegang otoritas penting dalam menggerakkan para santri. Dengan adanya gotong royong dan pengangkutan sampah dua kali dalam satu minggu, maka dalam satu minggu ada empat truk sampah yang teratasi. Bila dikalikan empat truk sampah dalam satu minggu selama penelitian ini berlangsung dari bulan April-Mei-Juni-Juli-Agustus sampai September berarti sudah 72 truk sampah teratasi dari pelaksanaan penelitian ini. Belum lagi sampah- sampah yang dibakar, didaur ulang; untuk menghiasi banjar pada peringatan perayaan hari kemerdekaan RI, 17 Agustus dan satu muharram $1440 \mathrm{H}$. dan yang diangkut truk sampah pada 4 kali kegiatan gotong royong massal.

Sedangkan partisipasi dan kemandirian dalam hal pengembangan potensi wisata terlihat dari antusias para pokir dalam mengikuti pengarahan dan pelatihan duta wisata. ${ }^{53}$ Untuk menjamin Selain gerakan aksi untuk menjamin keberlangsungan diupayakan lahir pemimpin lokal yang menjadi penggerak kegiatan ini, dilakukan melalui pemilihan duta kebersihan diantara para pokir.

\section{Pembahasan}

Pemeliharaan kebersihan di lingkungan pesantren Musthafawiyah adalah persolan utama dan pertama yang harus diselesaikan. Baik berkenaan dengan mengatasi masalah di lingungan pesantren sekaligus langkah awal pengembangan potensi wisata lingkungan pondok pesantren. Karena bagaimana mungkin potensi wisata dapat dikembangkan bila kondisi pesantren

53 Pembekalan bagi calon peserta duta Pariwisata oleh ibu Natalina dari dinas Pariwisata Kab. MADINA 
Vol. 11, No. 1 (Juni 2019)

jauh dari nilai bersih. Persoalan pemeliharaan kebersihan di lingkungan peantren tidak terlepas dengan jumlah pokir yang mencapai 12.578 dan kehidupan santri yang berbaur dengan masyarakat sekitar pesantren.

Hasil penelitian menemukan bahwa satu orang pokir minimal dapat menghasilkan tiga kantong sampah plastik setiap kali membeli lauk-pauk atau nasi di kedai-kedai nasi terdekat. ${ }^{5455}$ Peneliti melihat ada pergeseran nilai di tengah-tengah masyarakat termasuk para santri. Yaitu pola hidup instan dan tidak mau lelah. Dengan menggunakan plastik, selain murah dan praktis; tidak perlu mencuci. Padahal sampah plastik ini berdanpak negative bagi lingkungan. Hal ini tentunya bertentangan dengan gerakan pemerintah dalam pemeliharaan lingkungan dengan gerakan kurangi pemanfaatan plastik. Sampah-sampah ini belum ditambah sampah bungkus jajanan ringan, minuman kemasan,

\footnotetext{
${ }^{54}$ Berdasarkan pantauan peneliti plastik langsung dijadijan wadah untuk meletakkan nasi, dan lauk pauk yang dibeli pokir di warung sekitar pesantren. Budaya membungkus daun pisang sepertinya sudah berganti dengan memanfaatakan plastik dengan alasan praktis. Observasi tanggal 7 Agustus 2018 di salah warung nasi yang terletak di lokasi pesantren.
}

permen dan lain-lain. Edukasi yang intensif dan kepedulian semua pihak dibutuhkan dalam gerakan aksi perubahan mewujudkan lingkungan pesantren yang bersih. Baik pihak pesantren, pemerintah daerah, masyarakat sekitar maupun alumni.

Dari jumlah pokir yang ada dan volume sampah yang dihasilkan, maka pengangkutan sampah dua kali dalam satu minggu (kamis dan jumat) masih dinilai kurang. Volume sampah yang dihasilkan membutuhkan minimal satu kali pengangkutan truk sampah setiap harinya. Dalam hal ini "jasa" sungai Aek Singolot dengan airnya yang deras, sangat membantu dalam "menyelesaikan" persoalan sampah di lingkungan pesantren ini selama bertahun-tahun. Tanpa adanya sungai ini dapat dipastikan akan terjadi penumpukan sampah pokir yang menggunung. Meski demikian dibutuhkan upaya serius agar kelestarian sungai Aek Singolot dapat terjaga dan dapat diwariskan ke calon-calon pokir Musthafawiyah yang akan datang.

Banyak pesantren yang memiliki masalah dengan pemenuhan kebutuhan air bagi para santrinya. Lain halnya dengan pesantren Musthafawiyah, 
masalah kebutuhan ribuan santri akan air, teratasi dengan adanya sungai Aek Singolot. Jadi meskipun penelitian ini kemudian di fokuskan pada pemeliharaan kebersihan di lingkungan pesantren, namun sesungguhnya berimbas pada pemeliharaan kebersihan sungai Aek Singolot. Karena gerakan ini telah mengurangi jumlah volume sampah yang dibuang ke aliran sungai Aek Singolot, meski dalam volume yang sangat kecil. Demikian juga jika potensi wisata pesantren dapat terekspose maka dengan sendirinya potensi wisata sungai Aek Singolotpun dapat berkembang. Arus sungai yang deras dapat menjadi sarana olah raga arung jeram, seperti yang dilakukan para pokir secara tradisional.

Keindahan aliran sungai Aek Singolot, keunikannnya (tidak adanya hewan air yang dapat hidup di aliran sungai ini), serta aktifitas thaharah ribuan santri pada dasarnya juga merupakan nilai potensi wisata yang cukup tinggi. Potensi-potensi inilah yang perlu diekspose ke dunia luar agar diketahui banyak orang. Pengembangan potensi wisata yang ditawarkan adalah konsep wisata syariah. Sesuai dengan karakteristik pesantren sebagai lembaga pewaris nilai-nilai keislaman, maka karakteristi keislaman harus dijadikan dasar pengembangan. Oreantasi wisata rohani bukanlah keuntungan ekonomi semata, tapi unsur spiritual harus di tonjolkan dan dikedepankan. Untuk itu dibutuhkan duta-duta wisata dari kalangan pokir yang memiliki karakteristik keislaman yang kental.

Disisi lain pemeliharaan kebersihan pesantren yang rendah sudah menjadi budaya yang sulit diubah. Peneliti melihat langkah awal yang harus dilakukan adalah dengan memutus budaya yang sudah turun temurun dari generasi ke generasi. Upaya ini dilakukan dengan menerapkan peraturan yang mengikat. Untuk ini dibutuhkan sikap tegas pesantren melalui perpanjangan tangannya yaitu, dewan pelajar dan pengurus banjar untuk mensosialisasikan peraturan, menegak peraturan dan memberi sanksi bagi pelanggar peraturan. Langkah lain yang dapat ditempuh adalah dengan pendidikan akhlak bagi para pokir dalam mengamalkan ajaran Islam tentang kebersihan. Pemetaan awal penelitian ini; persoalan mendasar yang peneliti temukan adalah tidak adanya pendidikan akhlak tentang kebersihan dalam tataran 
praktis. Peneliti mengakui untuk tataran teoritis dengan kemampuan retorika, maka tidak diragukan lagi para pokir dapat menjadi da'i penyampai ajaran Islam tentang kebersihan dalam bentuk dakwah bi al-lisan, namun hal ini tidak sepadan dengan dakwah bi alhal/perbuatan. Untuk itu dibutuhkan pendidikan akhlak. Satu sistem pendidikan yang mengitegrasikan konsep dan nilai.

Untuk mengatasi masalah ini peneliti merekomendasikan kelulusan matapelajaran fiqh thaharah dan fiqh ibadah hendaknya memperhatikan pengejawantahan nilai kebersihan dalam kehidupan sehari-hari santri. Kegiatankegiatan yang menggugah kesadaran akan kebersihan pelu ditingkatkan, baik dalam bentuk "jumat bersih" atau pokir hebat, tanpa sampah" dan nama kegiatan lainnya.

Dalam semua keterbatasan, tidak dapat dipungkiri bahwa kegiatan ini sudah berhasil memberdayakan pokir dalam pemeliharaan kebersihan dan pengembangan potensi wisata pesantren. Terutama dalam mengatasi penumpukan volume sampah yang sangat luar biasa di lingkungan pesantren. Bila kebersihan mengalami perubahan maka dengan sendirinya potensi wisatapun dapat didongkrak. Keberhasilan pemberdayaan santri ini dapat dilihat dari partisipasi, kemandirian dan keberlangsungan aksi perubahan, meski dalam skop yang sangat terbatas; hal ini disebabkan besarnya jumlah subyek pendampingan mencapai 5945 orang, untuk mengatasi sampah 12.578 santri, sementara waktu dan dana penelitian sangat terbatas. Wallhu a'lam bi ash shawaf.

\section{E. Kesimpulan}

Jumlah santri yang mencapai 12.578 orang dan tersebar di 1846 pondok di 35 banjar pada dasarnya memiliki potensi sebagai sumber masalah sampah dan menyebabkan rendahnya pemeliharaan kebersihan di lingkungan pesantren. Disisi lain keunikan pesantren dengan keberadaan 1846 pondok dan aktifitas harian ribuan santri dengan penampilannya yang khas, tentunya memiliki potensi wisata yang potensial untuk dikembangkan. Pemecahan kedua problem ini dapat dilakukan dengan pemberdayaan santri melalui kegiatan;

1) Membuka wawasan dan kesadaran santri akan persoalan kebersihan dan potensi wisata pesantren, 
melalui kegiatan Fokus Group Discussion (FGD) dan pelatihan.

2) Menjalin kerjasama dengan pemerintah daerah melalui instansi terkait seperti Dinas Lingkungan Hidup, dinas pariwisata, pemerintahan kecamatan dan desa serta alumni (KAMUS)

3) Melakukan aksi perubahan, berupa gotong royong secara massal dan perlombaan kebersihan antar banjar.

4) Membangun komitmen semua pihak melalui penandatangan komitemen bersama mewujudkan pesantren bersih.

5) Memilih tokoh-tokoh lokal sebagai uapaya menjamin keberlangsungan program perubahan melalui pemilihan duta pariwisata dan duta kebersihan dari kalangan santri.

Kegiatan ini sudah berhasil memberdayakan santri dalam pemeliharaan kebersihan dan pengembangan potensi wisata pesantren hal ini dapat dilihat dari pasrtisipasi, kemandirian dan keberlangsungan aksi perubahan. Keterbatasan penelitian ini adalah subyek dampingan yang sangat besar, sementara waktu penelitian sangat singkat dan dana penelitian yang sangat minim.

\section{Daftar Pustaka}

Affandi, Agus. (2004). Modul Participatory Action Research (PAR); Untuk Pengorganisasian Mayarakat (Community Organizing), Surabaya: LPPM UIN Sunan Ampel.

Ali, Muhammad. (2014). Memahami Riset Prilaku Sosial, Jakarta: Bumi Aksara.

Cholisin. (2011). Pemberdayaan Masyarakat, Disampaikan pada Gladi Manajemen Pemerintahan Desa Bagi Kepala Bagian/Kepala Urusan Hasil Pengisian Tahun 2011 Di Lingkungan Kabupaten Sleman.

M. Bashori Muchsin, Upaya Pondok Pesantren Dalam Pemberdayaan Masyarakat Sekitar Hutan (Efforts of the Pondok Pesantren to Empower Societies Living at Surrounding Forest Areas), WACANA Vol. 12 No. 2 April 2009.

Mikkelsen, Britha. (2011). Metode Penelitian Partisipatoris dan Upaya Pemberdayaan, Jakarta: Obor. 
Mulyana, Deddy. (1998). Komunikasi Antarbudaya, Bandung: Remaja Rosdakarya.

Nurochim, Sekolah Berbasis Pesantren sebagai salah satu model pendidikan Islam dalam perubahan sosial, jurnal Al-Tahrir vol 16 No. 1 Mei 2016.

Pitana, I Gede \& Gayatri, Putu G. (2005). Sosiologi Pariwisata, Yogyakarta: ANDI.

Raharjo, Dawan. (1983). Pesantren dan Pembangunan, Jakarta: LP3ES.

Rahim, Husni. Pola Pemberdayaan masyarakat Melalui pesantren, Jakarta: Ditkapontren Kelembagaan Agama Depatemen Agama RI.

Rudi, Hardianto, Pemberdayaan Santri Pondok Pesantren Musthafawiyah Di Era Globalisasi (Studi Kasus Pondok Pesantren Musthafawiyah), Al-Ishlah: Jurnal Pendidikan -Vol. 9, No. 2, 2017.

Rustam Ibrahim, pesantren dan pengabdian masyarakat, dalam jurnal Al-tahrir, Vo. 16 No. 1

Sumadai, Islam dan Seksualitas: Bias Gender dalam humor Pesantren, dalam Jurnal el-harakah, Vol. 19, No. 1 Januari-Juni 2017

Supriyantini Istiqomah, Pemberdayaan dalam konteks pengembangan masyarakat Islam. Komunitas, Jurnal Pengembangan Masyarakat Islam, Volume 4, Nomor 1, Juni, 65-78, 2008.

Weber, Max. (2002). Die Protestantische Ethik and der "Geist" des Kapitalismus, diterjemahkan oleh Talcott Parson, The Protestant Ethic and the spirit of capitalism, , New York: Char Les Scribner's Son, 1959, (terjemahan Yusuf Priyasudiarja, Etika Protestan dan Semangat Kapitalisme, Surabaya: Pustaka Promethea. 